\title{
List of Species and Conservation Status of Avifauna and Small mammal around Bade Segment Area of River Yobe, Yobe State, Nigeria
}

\author{
Adam, L. I. ${ }^{1}$, Abdullahi, M. ${ }^{2}$, Kwaga, B. T. ${ }^{3}$, Dadile, A. M. ${ }^{4}$, Danturai S. A. ${ }^{5}$ \\ 1,2,4 Department of Forestry and Wildlife Management, Federal University, Gashua, Yobe State \\ ${ }^{3}$ Department of Forestry and Wildlife Management, Modibo Adama University, Yola, Adamawa State \\ ${ }^{5}$ Department of Forestry and Wildlife, Kano University of Science and Technology, Wudil, Kano State
}

\begin{abstract}
The study was carried out to assess a Checklist of avifauna and small mammal species along Bade catchment area of Yobe State, Nigeria. Preliminary survey was conducted around the river, three (3)_habitat types were identified; (river bank, farm lands and flood plain). The line transect was $8 \mathrm{~km}$ in length. Two (2) transects were established per habitat type, making a total of six (6) transects. The transects were $100 \mathrm{~m}$ apart to the left or right in order to avoid double counting of species. A distance of $200 \mathrm{~m}$ was maintained between each habitat. The data obtained were analyses using descriptive statistics (Frequency tables and Charts were used to portrayed the findings. The result of the study; showed that a total of 50 bird species in 28 families were recorded. RB had the highest individuals of Fifty (50) species while FP has the lowest with ten (10) species._The Bird family Columbidae has the highest number with six (6) of species, while the lowest were Ardeidae, Sturnidae and Tytonidae with one species in each of the habitat types. However, checklist of small mammal species also indicated that a total of 6 species of small mammals belonging to 4 families were identified. The result of the study shows that the family Muridae has 3 species which was the highest number of per family identified in the study area, this is due to the fact that Muridae family are the most common small mammals in the study area. And both bird small species fell under least concern (LC) category except Pallid Harrier Circus macrourus which felled under near threatened (NT) species. However, awareness campaign should also be organize for the residents around the study area_on the presence, distribution of bird and small mammal species and also disturbing effect of their activities on bird and small mammal around the segment area of river Yobe.
\end{abstract}

KEY WORDS: Avifauna, Checklist, River Yobe, Small Mammal.

\section{INTRODUCTION}

Bird species are warm blooded vertebrates in the scheme of biological classification. They belong to the phylum chordate because of the presence of backbone and to the class Aves for possessing feathers on their bodies (Kwaga, et al., 2017). There are approximately 8,700 living species and more than 1,000 extinct species identified from fossil remains (Safra, 1998). They are the good indicators of ecological status of any given ecosystem (Castelletta, et al., 2000). Avian species are important component of the health of an ecosystem furthermore, plays an informational role in attracting public attention to natural habitat (Bibi and Ali, 2013). Birds have been considered as useful biological indicators because they are ecologically versatile and can found in all kinds of habitats (Sivaperuman and Jayson, 2006). Many frugivorous birds are of tremendous importance as pollinators and play a key role in seed dispersal (Sekercioglu, 2006). Migration of birds is a common response to environmental periodicity (Berthold 2001). In Nigeria, four (4) avifauna species; Anambra waxbill (Estrilda poliopareia), Ibadan Malimbe, (Malimbus ibadanensis), Jos Plateau indigo-bird (Vidua maryae) and the Rock Fire-Finch (Lagonosticta sanguinodorsalis) are endemic to the country, making them globally important species for conservation (Nigeria National Biodiversity strategy and action plan NBSAP, 2007).

Previous studies on the avifauna resources were carried out at Dagona Waterfowl Sanctuary by Lameed, 2011; Hadejia-Nguru Wetlands by Ringim and Sulaiman, 2017; Sabo, 2016. All these studies covered the Dagona-Nguru-Hadejia wetland which is congruent with river Yobe. Even though, a recent study was conducted on small mammals in Federal University Gashua by (Adam et al 2021).

Nigeria has a vast and unique diversity of small mammals, which has been surveyed and reported on extensively (Igbokwe, et al, 2016). Small mammals have long been used as bio-indicators and model organisms to study patterns of species abundance and diversity along different land use gradients (Michel, et al, 2007). Small mammal influence the structure and composition of forests 


\section{International Journal of Current Science Research and Review}

ISSN: 2581-8341

Volume 04 Issue 12 December 2021

DOI: 10.47191/ijcsrr/V4-i12-18, Impact Factor: 5.825

IJCSRR@ 2021

www.ijcsrr.org

through consumption and seeds dispersal, pollination and prey for other animals species such as snakes, birds and mammals, which are often of greater conservation concern (Chung and Corlett, 2006). Small mammals constitute a large proportion of the prey base for avian and mammalian predators (Fryxell Rosenberg et al. 2003). Alterations in the community structure of these small mammals can be used as alternative and a quick way of measuring environmental disturbance, due to their sensitivity to small changes in the environment (Avenant, 2011) Some of these small mammals are also plants pests and carriers of zoonotic diseases (Datiko and Bekele, 2014).

There is paucity of information and on the competition of bird and small mammal species around the River Yobe, (bade segment area). Previous studies on the avifauna resources were carried out at Dagona Waterfowl Sanctuary by Lameed, 2011; Hadejia-Nguru Wetlands by Ringim and Sulaiman, 2017; Sabo, 2016. All these studies covered the Dagona-Nguru-Hadejia wetland which is congruent with river Yobe, in which this study covered. Even though, a recent study was conducted on small mammals species in Federal University Gashua by (Adam et al 2021). However, no studies have covered the eastward section of the River (Bade catchment area) particularly Gashua. Hence the need for this study which is to assess bird and small mammal species around Bade segment Area of River Yobe, in order to provides a list and IUCN status of bird and small mammal species in the area.

The Data obtained from the study provides baseline information on the species list and iucn status and also create an understanding of the current Avian and small mammal species present in the study area for better future studies, conservation and management plan initiatives around segment of river bade section. Moreover, the list of avian and small mammals produced in the study area, couple with checklist of other areas in the country might be useful in updating the country's fauna species, since not all the ecosystems were covered.

\section{METHODOLOGY}

\section{Study Area}

River Yobe, is also known as the komadougou-Yobe in French is a river in West Africa that flows into Lake Chad through Nigeria and Niger; in Nigeria, it covered an eastern extension of Bade-Nguru wetlands sector. The wetlands are rich community which housed numerous plants and animals species, including vertebrates, invertebrates, seeds, and tubers, which provides shelter, foods and water for birds and small species (David et al, 2009; Muhammad et al, 2012), and supporting valuable bird species such as songbirds and shorebirds besides a wide habitat range (Anderson, 2003). Wetlands also serving as a roosting, breeding and thermoregulation ground for many bird's species (Shiemelis and Afework, 2008),

This research was carried out at Gashua part of the Bade L.G.A. catchment area of River Yobe. Gashua is the headquarters of Bade L.G.A. River Yobe has a total land size of $148,000 \mathrm{~km}^{2}$ (IUCN, 2009). It is situated in semi-arid sub-Sahara region of Nigeria in Yobe State. Popular towns alongside of the River include Gashua, Geidam in Nigeria and Damasak in Nigeria and Diffa in Niger Republic (Kole, 1997). The study site lies between latitudes $12^{\circ} 52^{\prime} 5$ North and longitudes $11^{\circ} 2^{\prime} 47$ East and at an average elevation is about 299 m above sea level (Wakawa, et al., 2017). Bade Local Government area has an area of $772 \mathrm{~km}^{2}$ (Yusuf, 2015), with estimated population of about 139,782 (NBS, 2006). It Shares a common boundary with Bursari, Yunusari, Jakusko and Karasuwa Local Government areas of Yobe state, as shown in (Fig. 1). Agriculture is the major economic activity of this area due to the presence of rivers, stream and tributaries notably, River Yobe. Gashua area provides opportunity for the people of the community to engage in irrigation farming, which contributes a high share of rice production to the state and fishing activities (Hamidu, 2015). The few scattered trees found within her vegetation range are mostly the Gum Arabic (Acacia senegal), Baobab (Adansonia digitata) and Doun palm (Hyphaen thebaica). Acacia seyal, Acacia nilotica, Faidherbia albida, Maerua crassifolia, Tamarindus indica, Anogeissus leiocarpus, Bauhinia refescence, Ziziphus muritiana and Ziziphus spina-christi (Wakawa et al., 2017). Neem trees Azadiracta indica are found in area of settlement. Grasses are very short that complete their life cycle within the few three month of rainfall. 
International Journal of Current Science Research and Review

ISSN: 2581-8341

Volume 04 Issue 12 December 2021

DOI: 10.47191/ijcsrr/V4-i12-18, Impact Factor: 5.825
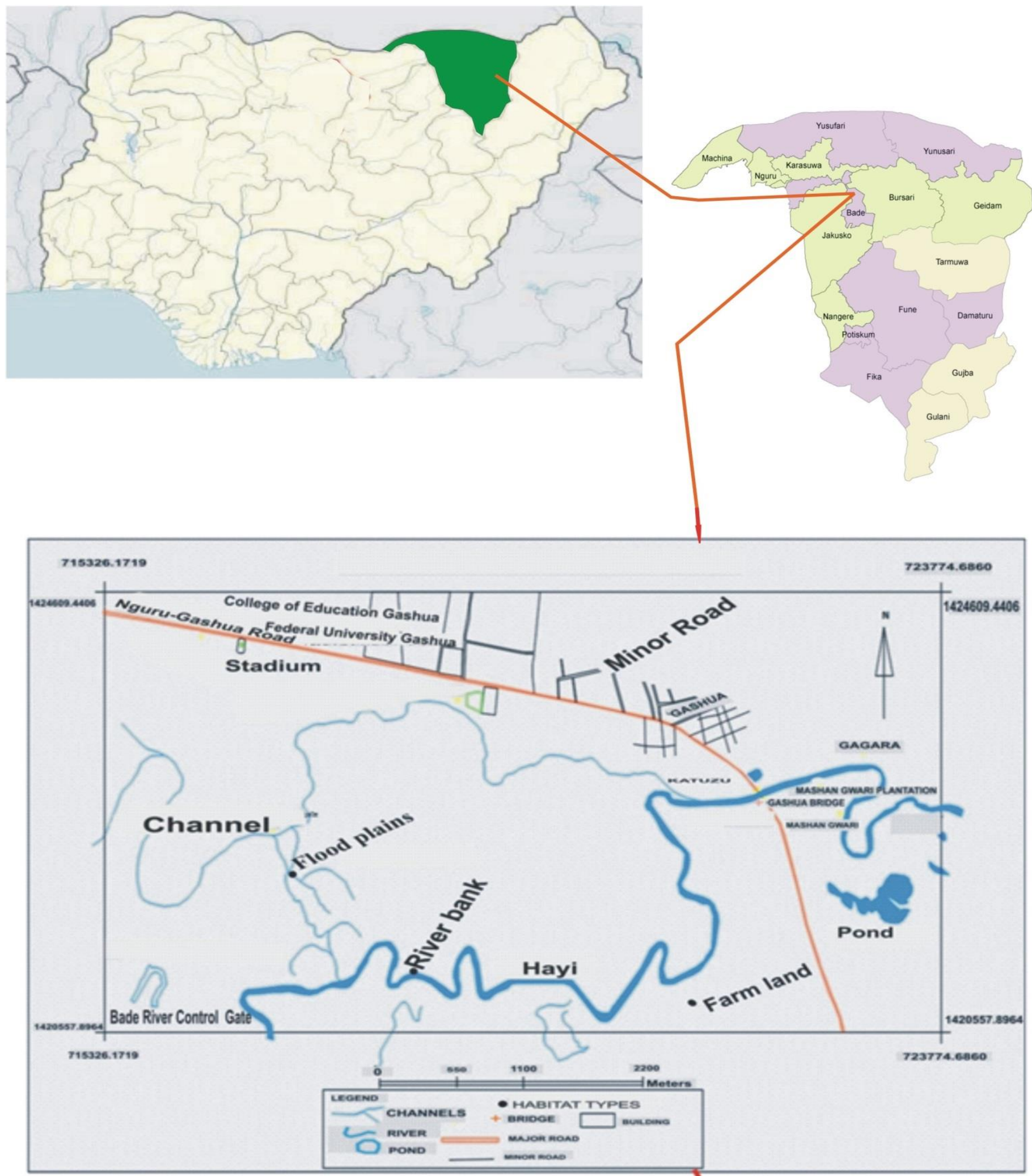

Figure 1: Map of River Yobe Showing Bade Catchment Area in Yobe State

Source: Google earth image, open source software (c) (2017) 


\section{International Journal of Current Science Research and Review}

ISSN: 2581-8341

Volume 04 Issue 12 December 2021

DOI: 10.47191/ijcsrr/V4-i12-18, Impact Factor: 5.825

IJCSRR@ 2021

WwW.ijesrr.org

\section{Data collection techniques}

This survey was conducted from March-June 2018. It was carried out using Line Transect method. The line transect was $0.5 \mathrm{~km}$ in length. Two (2) transects were established per habitat type; River Banks (RB), Farm Lands (FL) and Flood Plains (FP). The transects were $100 \mathrm{~m}$ apart to the left or right in order to avoid double counting of species. A distance of $200 \mathrm{~m}$ was maintained between each habitat. When each Habitat is visited, a line transect was walked in the morning hour from 6:00 am-10:00 am and evening 3:00 pm6:00 pm. These periods coincide with the time when some animals are most likely to search for food and water (Kwaga, et al., 2017). For River Bank habitat, morning observations were taken on one side of the river and evening observations was also taken at the other side respectively. Each transect in a habitat was visited four (4) times, which resulted in each habitat being visited Sixteen (16) man-days during the study, making a total of Forty eight (48) man-Days. Two observers move slowly as possible at a rate of $0.2-0.5 \mathrm{~km} / 30$ minutes stopping occasionally at every $50 \mathrm{~m}$ point along each transect to listen and watch for bird and small mammals species. Once the observers reach the point, they stay for Five (5) minutes after arrival to allow the birds to settle. When a bird or flock is sighted or encountered, the following information was recorded: Name of the species and Number sighted. Birds were viewed with the aid of 12 × 32 Bushnell Binoculars and identified using the Field Guide to birds of Western Africa by Borrow and Demey (2014). And Jonathan Kingdon Field Guide to African Mammals (Kingdon, 2015), was used to identify small mammals species in the study area.

Other Methods which used in Identification of birds and Small Mammals species in the study area

The methods used in identification of bird and mammal species in the study area were highlighted as follows:

i. Indices: - This follows Koster and Hart (1988) and Akosim and Mbaya (2014), method in which wildlife populations' studies must rely on the interpretation of animals sign. Wildlife signs such as scales of reptiles, fresh droppings, different holes and caves, types of nest, foot prints and animal dead body were considered for interpreting the presence and estimating wildlife population (Adamu, 2006). This was equally observed in the process of moving along the transect line. And many burrows, dead animal bodies and nest were seen as shown in (plate 2 and 3).

ii. Market Survey: - Bush meats at the local market in the study area were identified and united as adopted by Akosim and Mbaya, (2014). One bush meat market was identified in Gashua town. The visit to the bush meat market in Gashua was carried out between 10:30 am-01:00 pm throughout the period of the study in every Wednesday of a week which is the market day for Gashua town.

\section{Status Categories of Mammals and Birds}

Categories outlined by (Ezealor 2002; Mbaya, and Malgwi, 2010). were used to assign the status of mammals and of birds. This is as follows;

$\mathbf{V u}=$ Vulnerable (Likely to become endangered if the factor that is posing threat persists).

LR/ cc = Low risk-conservation dependent (Species in no immediate danger but survival will depend on implementation of effective conservation measures in its range).

Lc= least concern. Categories on the IUCN red list of threatened species which indicates that a taxon has been evaluated and does not qualify for critically, endangered, endangered, and vulnerable or near threatened.

NT= near threatened (species is approaching the threshold of vulnerability)

$\mathbf{E N}=$ Endangered (species is unlikely to survive if the factor that is posing threat persists).

$\mathbf{R B}=$ Resident breeder

$\mathbf{R}\{\mathbf{B}\}=$ Resident but breeding not approved. $\mathrm{PM}=$ Palearctic migrant

AFM= Migrates within Nigeria

DD = Data deficient.

\section{Statistical Analysis of Data}

The data obtained were analyses using descriptive statistics (frequency tables, means, charts and diagrams following Wakawa et al,(2016). 


\section{International Journal of Current Science Research and Review}

ISSN: 2581-8341

Volume 04 Issue 12 December 2021

DOI: 10.47191/ijesrr/V4-i12-18, Impact Factor: 5.825

IJCSRR@ 2021

www.ijcsrr.org

\section{RESULTS}

\section{Checklist of avifauna species in the study area}

Result showed that a total of Fifty (50) Species of birds belonging to twenty eight (28) families were recorded. All species recorded occurred around the River Bank (RB) area, Twenty Nine (29) species occurred around Farm Lands (FL) and Ten (10) species in Flood plain (FP) areas respectively. Six (6) species; Great egret Egretta alba, Crested lark Galerida cristata, Abyssinian roller Coracias abyssinicus, Rose Ringed Parakeet Psittacula krameri, Bush petronia Gymnoris dentata Northern grey-headed sparrow Passer griseus occurred across all three (3) habitat types (Table 1). Result also indicated that family Columbidae had the highest number of species six (6), followed by Accipitridae (5), while Leporidae, Erinaceidae, Nesomyidae, Gerbillinae, Soricidae, Pteropodidae and Sciuridae has the lowest representative by One (1) species each as shown in (Fig. 2). Long-tailed glossy Starling Lamprotornis caudatus, Black-headed Lapwing Vanellus tectus and Barn Owl Tyto alba were also encountered their dead body in th e study area as shown in (Plate 2) is just natural dead. However, river bank

\section{Check list of small mammals in the study area}

Table 2 shows the checklist of small mammal species and their mode of identification. A total of Ten (10) species of some mammals belonging to Nine (9) families were identified. The result of the study indicated that the family Muridae has the highest number of three (3) species. While Herpestidae Erinaceinae, Nesomyidae, Canidae, Felidae and Leporidae have the lowest representative by (1) species each recorded in the study area. The highest number of family in Muridae as shown in (Figure 2) might be due to the fact that they are the most common small mammal's species inhabiting the study area. This findings is in line with the work of Atiku et al, (2014) who reported that Muridae are the most common mammals which by implication has the highest number of species in Wassaniya forest reserve Sokoto state Nigeria, while the rest of the families has only single (1) specie each. The findings further reveals that most of the species were identified through Dead Animal (DA) and Visit to bush meat processing and selling centers (BMPSC) which has 6 species each, then followed by Direct Sighting (DS) and Burrow (BURR) which also has 4 species each. Suricata suricatta, Vulpes pallid, Cricetomys gambianus Lepu saxatilis Xeru erythropu Lepu saxatilis Lepu saxatilis and Suncus varilla were identified through BMPSC, the result also demonstrated that almost all birds and small mammal species felled under LC (least concern) in IUCN red list of threatened species except Pallid Harrier Circus macrourus which felled under NT (Near threatened) in the conservation status as shown in (Table 2 and table 3 )

Table 1: List and IUCN status of avian species encountered at the three habitat types in Bade Catchment Area of River Yobe

\begin{tabular}{|c|c|c|c|c|c|c|c|}
\hline \multirow{2}{*}{$\begin{array}{l}\mathbf{S} / \mathbf{N} \\
\mathbf{N N N}\end{array}$} & \multirow{2}{*}{ Family } & \multirow{2}{*}{$\begin{array}{l}\text { Species } \\
\text { Common Name }\end{array}$} & \multirow{2}{*}{ Scientific Name } & \multicolumn{3}{|c|}{ Habitat Types } & \multirow{2}{*}{$\begin{array}{l}\text { IUCN } \\
\text { Status }\end{array}$} \\
\hline & & & & $\mathbf{R B}$ & FL & $\mathbf{F P}$ & \\
\hline 1 & Bucerotidae & Red-Billed Hornbill & Tockus erythrorhynchus & $x$ & - & $x$ & $\mathrm{LC}$ \\
\hline 2 & & African Grey Hornbill & Tockus nasutus & $x$ & - & $x$ & $\mathrm{LC}$ \\
\hline 3 & Ciconiidae & Abdim's Stork & Ciconia abdimii & $x$ & $x$ & - & $\mathrm{LC}$ \\
\hline 4 & Accipitridae & African Cuckoo Hawk & Aviceda cuculoides & $x$ & - & - & $\mathrm{LC}$ \\
\hline 5 & & Black-Shouldered kite & Elanus caeruleus & $x$ & $x$ & - & $\mathrm{LC}$ \\
\hline 6 & & Montagu's Harrier & Circus pygargus & $x$ & - & - & $\mathrm{LC}$ \\
\hline 7 & & Tawny Eagle & Aquila rapax & $x$ & - & - & $\mathrm{LC}$ \\
\hline 8 & & Pallid Harrier & Circus macrourus & $x$ & - & - & NT \\
\hline 9 & Charadriida & Black-headed Lapwing & Vanellus tectus & $x$ & $x$ & - & $\mathrm{LC}$ \\
\hline 10 & Ardeidae & Intermediate Egret & Egretta intermedia & $x$ & - & - & $\mathrm{LC}$ \\
\hline 11 & & Little Egret & Egretta garzetta & $x$ & - & - & $\mathrm{LC}$ \\
\hline 12 & & Great Egret & Egretta alba & $x$ & $x$ & $x$ & $\mathrm{LC}$ \\
\hline 13 & & Cattle Egret & Bubulcus ibis & $x$ & $x$ & - & $\mathrm{LC}$ \\
\hline 14 & Estrildidae & Cut-Throat Finch & Amadina fasciata & $x$ & - & - & $\mathrm{LC}$ \\
\hline 15 & & Red-Cheeked Cordon Bleu & Uraeginthus angolensis & $x$ & $x$ & - & $\mathrm{LC}$ \\
\hline 16 & & Red-Billed Firefinch & Lagonosticta senegala & $x$ & - & - & $\mathrm{LC}$ \\
\hline
\end{tabular}




\section{International Journal of Current Science Research and Review}

ISSN: 2581-8341

Volume 04 Issue 12 December 2021

DOI: 10.47191/ijesrr/V4-i12-18, Impact Factor: 5.825

IJCSRR@ 2021

\begin{tabular}{|c|c|c|c|c|c|c|}
\hline \multirow[t]{3}{*}{ Alaudidae } & Chestnut-backed Sparrow lark & Eremopterix leucotis & $x$ & $x$ & - & $\mathrm{LC}$ \\
\hline & Crested lark & Galerida cristata & $x$ & $x$ & $x$ & $\mathrm{LC}$ \\
\hline & Sun lark & Galerida modesta & $x$ & $x$ & - & $\mathrm{LC}$ \\
\hline Upupidae & Hoopoe & Uрира ерор & $x$ & $x$ & - & $\mathrm{LC}$ \\
\hline \multirow[t]{3}{*}{ Sturnidae } & Long-tailed glossy Starling & Lamprotornis caudatus & $x$ & $x$ & - & $\mathrm{LC}$ \\
\hline & Chestnut-Bellied Starling & Lamprotornis pulcher & $x$ & - & - & $\mathrm{LC}$ \\
\hline & Purple glossy Starling & Lamprotornis purpureus & $x$ & $x$ & - & $\mathrm{LC}$ \\
\hline \multirow[t]{6}{*}{ Columbidae } & Namaque Dove & Oena capensis & $x$ & - & - & $\mathrm{LC}$ \\
\hline & African mourning Dove & Streptopelia decipiens & $x$ & $x$ & - & $\mathrm{LC}$ \\
\hline & African collared Dove & Streptopelia roseogrisea & $x$ & $x$ & - & $\mathrm{LC}$ \\
\hline & Vinaceous Dove & Streptopelia vinacea & $x$ & $x$ & - & $\mathrm{LC}$ \\
\hline & Laughing Dove & Streptopelia senegalensis & $x$ & $x$ & - & $\mathrm{LC}$ \\
\hline & Speckled Pigeon & Columba guinea & $x$ & $x$ & - & $\mathrm{LC}$ \\
\hline Coraciidae & Abyssinian Roller & Coracias abyssinicus & $x$ & $x$ & $x$ & $\mathrm{LC}$ \\
\hline Timaliidae & Brown Babbler & Turdoides plebejus & $x$ & - & - & $\mathrm{LC}$ \\
\hline Phasianidae & Double-Spurred Francolin & Francolinus bicalcaratus & $x$ & $x$ & - & $\mathrm{LC}$ \\
\hline Iniidae & Grey-Backed Fiscal & Lanius excubitoroides & $x$ & - & - & $\mathrm{LC}$ \\
\hline Cistocalidae & Tawny flanked Prinia & Prinia subflava & $x$ & - & $x$ & $\mathrm{LC}$ \\
\hline Laniidae & Woodchat Shrike & Lanius senator & $x$ & - & $x$ & $\mathrm{LC}$ \\
\hline Corvidae & Pied Crow & Corvus albus & $x$ & $x$ & - & $\mathrm{LC}$ \\
\hline Scolopacida & Temminck' Stint & Calidris temminckii & $x$ & $x$ & - & $\mathrm{LC}$ \\
\hline Viduidae & Village Indigobird & Vidua chalybaeta & $x$ & - & - & $\mathrm{LC}$ \\
\hline Cuculidae & Senegal Coucal & Centrpus senegalensis & $x$ & $x$ & - & $\mathrm{LC}$ \\
\hline Motacillidae & Yellow Wagtail & Lanius senator & $x$ & $x$ & - & $\mathrm{LC}$ \\
\hline Alcedinidae & Pied Kingfisher & Motacilla flavor & $x$ & - & - & CL \\
\hline Psittaculidae & Rose-Ringed Parakeet & Psittacula krameri & $x$ & $x$ & $x$ & $\mathrm{LC}$ \\
\hline \multirow[t]{2}{*}{ Passeridae } & Bush Petronia & Gymnoris dentata & $x$ & $x$ & $x$ & $\mathrm{LC}$ \\
\hline & Northerngrey-headed Sparrow & Passer griseus & $x$ & $x$ & $x$ & $\mathrm{LC}$ \\
\hline Meropidae & European Bee-Eater & Merops apiaster & $x$ & - & - & $\mathrm{LC}$ \\
\hline \multirow[t]{3}{*}{ Ploceidae } & White-billed buffalo Weaver & Bubalornis albirostris & $x$ & $x$ & - & $\mathrm{LC}$ \\
\hline & Red-billed Quelea & Quelea erthrops & $x$ & $x$ & - & $\mathrm{LC}$ \\
\hline & Chestnut-Crowned Sparrow Weaver & Plocepasser superciliosus & $x$ & - & - & $\mathrm{LC}$ \\
\hline Caprimulgid & Spur-winged Lapwing & Vanellus spinosus & $x$ & $x$ & - & $\mathrm{LC}$ \\
\hline Tytonidae & Barn Owl & Tyto alba & $x$ & - & - & $\mathrm{LC}$ \\
\hline
\end{tabular}

$\mathbf{R B}=$ River Banks, $\mathbf{F L}=$ Farm Land, $\mathbf{F P}=$ Flood Plain, $\mathrm{x}=$ Present, $-=$ Absent and IUCN= International Union for the Conservation of Nature 
ISSN: 2581-8341

Volume 04 Issue 12 December 2021

DOI: 10.47191/ijcsrr/V4-i12-18, Impact Factor: 5.825

\section{RIVER BANK}

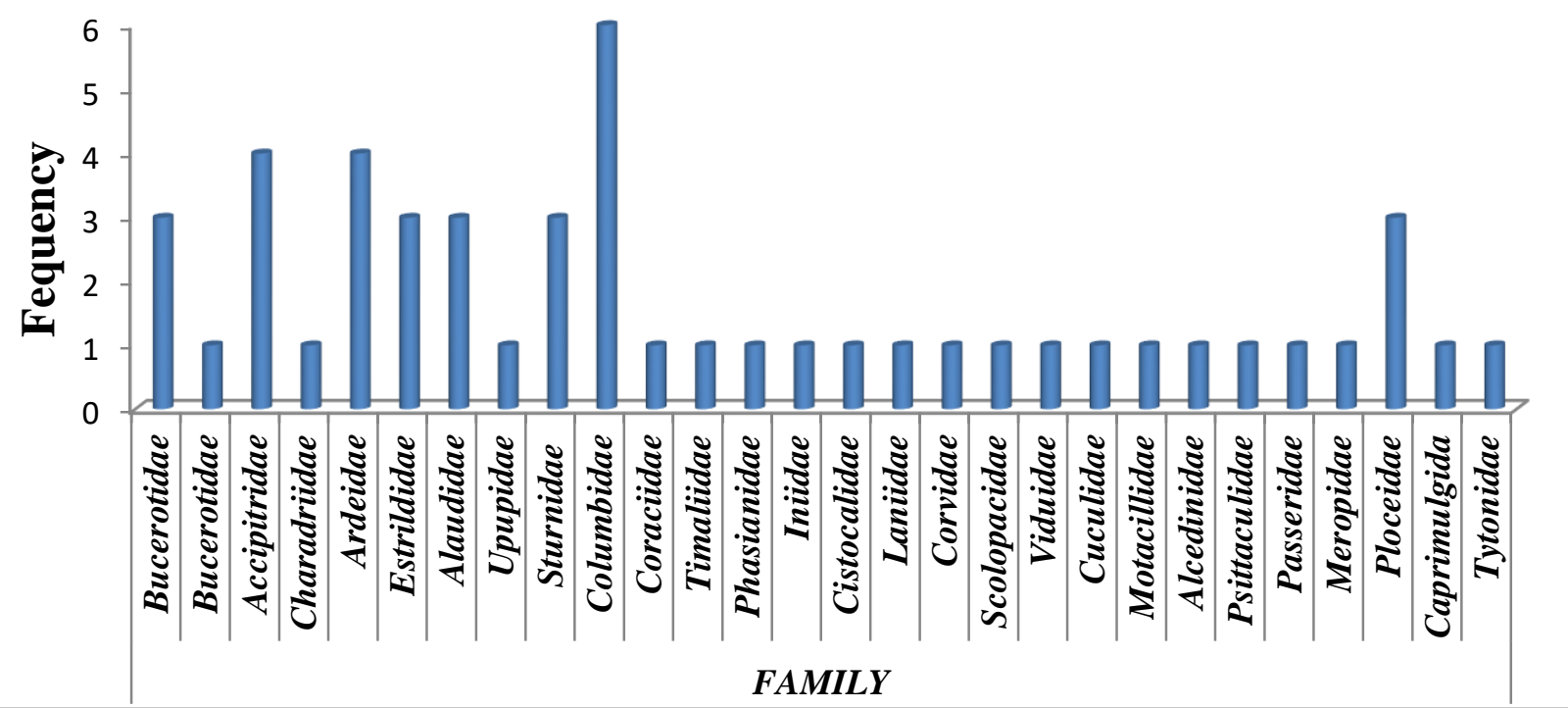

Figure 1: Frequency of family distribution of avifauna species identified at River Bank in the study area

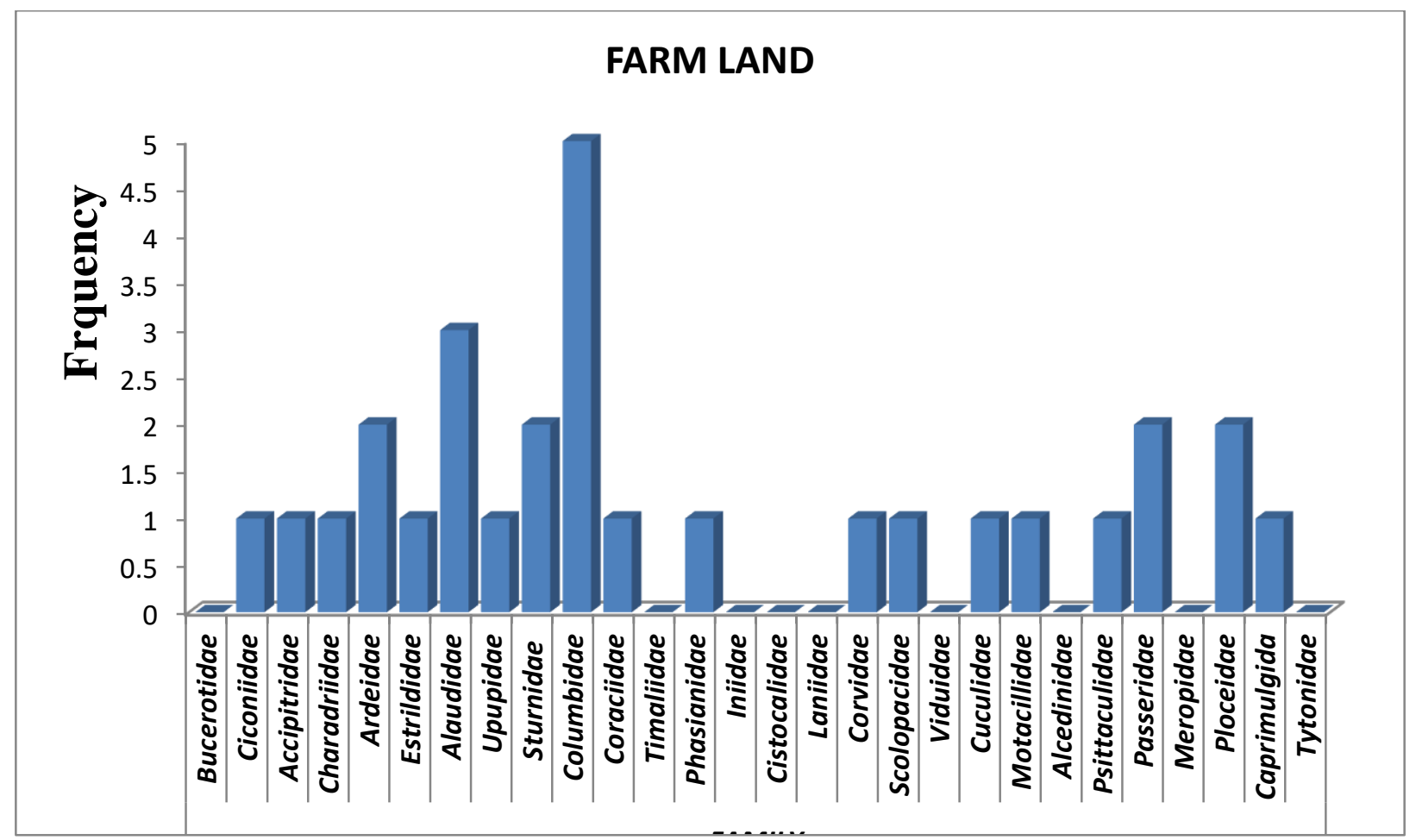

Figure 2: Frequency of family distribution of avifauna species identified at Farm Land in the study area 


\section{International Journal of Current Science Research and Review}

ISSN: 2581-8341

Volume 04 Issue 12 December 2021

DOI: 10.47191/ijesrr/V4-i12-18, Impact Factor: 5.825

IJCSRR@ 2021

www.ijjcsrr.org

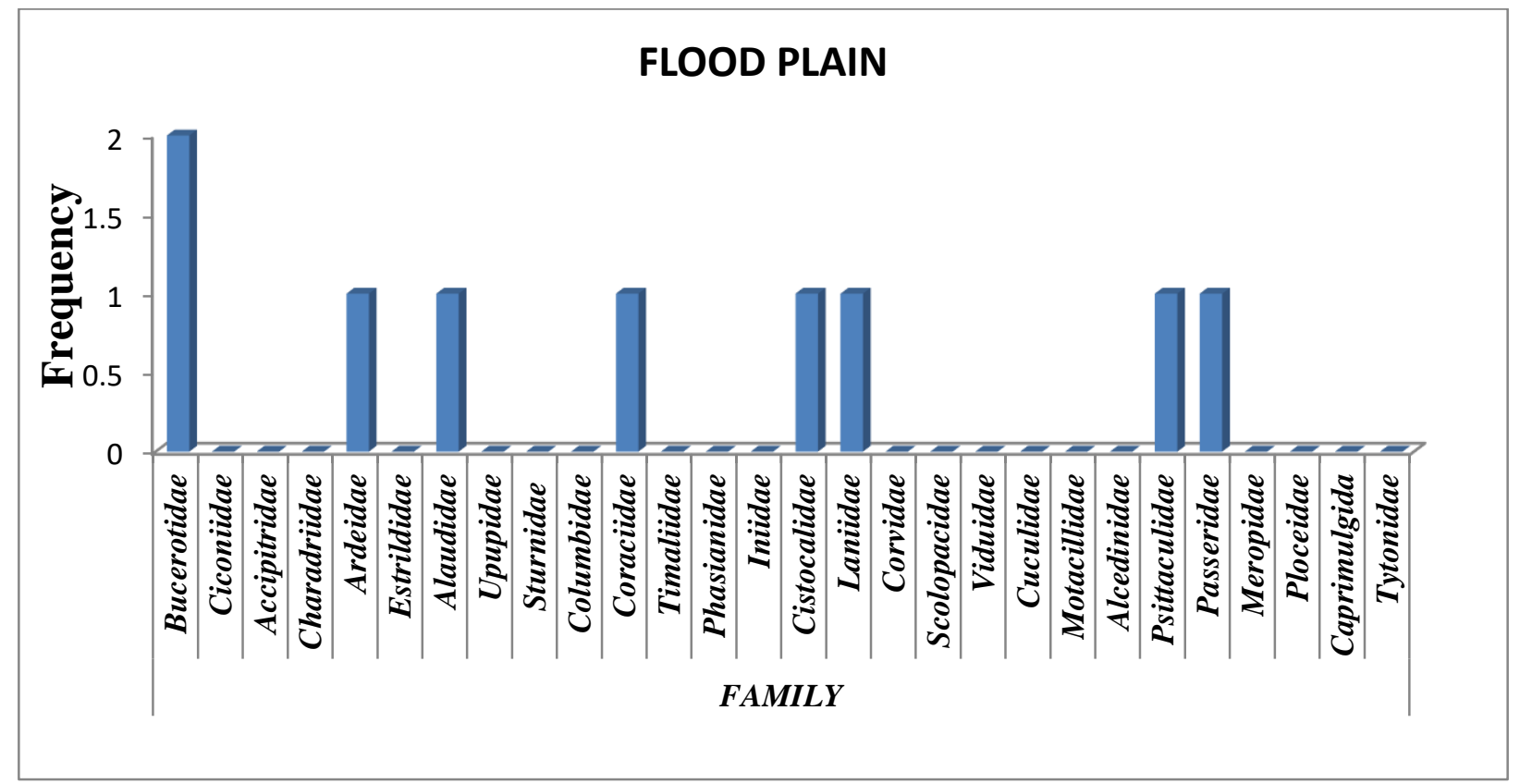

Figure 3: Frequency of family distribution of avifauna species identified at Flood Plain in the study area

Table 2: Checklist of small mammals' species encountered at Bade Catchment area of River Yobe

\begin{tabular}{|c|c|c|c|c|c|c|}
\hline \multirow[b]{2}{*}{ Family } & \multirow[b]{2}{*}{ Common name } & \multirow[b]{2}{*}{ Scientific Name } & \multicolumn{3}{|c|}{ Mode of identification } & \multirow[b]{2}{*}{ BURR } \\
\hline & & & DS & BMPSC & DA & \\
\hline Herpestidae & African mongoose & Suricata suricatta & - & $x$ & - & - \\
\hline Erinaceinae & African hedgehog & Altelerix albiventris & - & - & $x$ & - \\
\hline Canidae & African sand fox & Vulpes pallid & - & $x$ & - & - \\
\hline \multirow[t]{3}{*}{ Muridae } & Black rat & Rattus rattus & $x$ & - & - & $x$ \\
\hline & Bushveld Gerbils & Gerbilliscus leucogaster & $x$ & - & $x$ & $x$ \\
\hline & Short tail manicoot rat & Nesokia indica & $x$ & - & $x$ & $x$ \\
\hline Nesomyidae & Giant porched Rat & Cricetomys gambianus & - & $x$ & - & - \\
\hline Sciuridae & Ground Squirrel & Xeru erythropus & - & $x$ & - & \\
\hline Felidae & Wild cat & Felis silvestris & - & $x$ & $x$ & - \\
\hline Leporidae & Scrub hare & Lepu saxatilis & - & $x$ & $x$ & - \\
\hline Soricidae & Musk Shrew & Suncus varilla & - & - & $x$ & - \\
\hline
\end{tabular}

In the above table: DS= Direct Sighting BMPSC= Bush Meat Processing and selling Center DA= Dead Animal Burr $=$ Burrow $\times=$ Present $-=$ absent

Source: Field Survey (2018) 


\section{International Journal of Current Science Research and Review}

ISSN: 2581-8341

Volume 04 Issue 12 December 2021

DOI: 10.47191/ijesrr/V4-i12-18, Impact Factor: 5.825

IJCSRR@ 2021

www.ijesrr.org

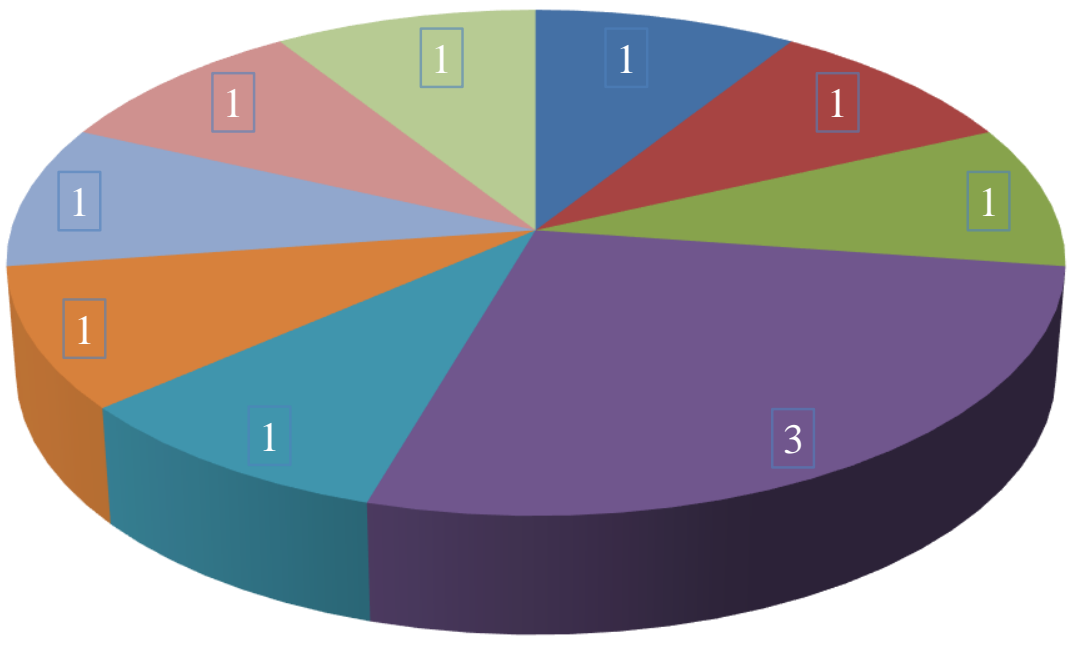

- Herpestidae

Erinaceinae

- Canidae

Muridae

Nesomyidae

- Sciuridae

Felidae

Leporidae

Soricidae

Figure 4: Frequency of family distribution of small mammal species identified in the study area

Table 3: IUCN status of small mammals' species encountered at Bade Catchment area of River Yobe

\begin{tabular}{|c|c|c|c|c|c|c|}
\hline \multirow[b]{2}{*}{ Common name } & \multirow[b]{2}{*}{ Scientific Name } & \multicolumn{3}{|c|}{ Mode of identification } & \multicolumn{2}{|r|}{ IUCN Status } \\
\hline & & DS & BMPSC & DA & BURR & Categories \\
\hline African mongoose & Suricata suricatta & - & $x$ & - & - & $\mathrm{LC}$ \\
\hline African hedgehog & Altelerix albiventris & - & - & $x$ & - & $\mathrm{LC}$ \\
\hline African sand fox & Vulpes pallid & - & $x$ & - & - & $\mathrm{LC}$ \\
\hline Black rat & Rattus rattus & $x$ & - & - & $x$ & $\mathrm{LC}$ \\
\hline Bushveld Gerbils & Gerbilliscus leucogaster & $x$ & - & $x$ & $x$ & $\mathrm{LC}$ \\
\hline Short tail manicoot rat & Nesokia indica & $x$ & - & $x$ & $x$ & $\mathrm{LC}$ \\
\hline Giant porched Rat & Cricetomys gambianus & - & $x$ & - & - & $\mathrm{LC}$ \\
\hline Ground Squirrel & Xeru erythropus & - & $x$ & - & & $\mathrm{LC}$ \\
\hline Wild cat & Felis silvestris & - & $x$ & $x$ & - & $\mathrm{LC}$ \\
\hline Scrub hare & Lepu saxatilis & - & $x$ & $x$ & - & $\mathrm{LC}$ \\
\hline Musk Shrew & Suncus varilla & - & - & $x$ & - & $\mathrm{LC}$ \\
\hline
\end{tabular}

In the above table: DS= Direct Sighting BMPSC $=$ Bush Meat Processing and selling Center DA= Dead Animal Burr $=$ Burrow $x=$ Present $-=$ absent and IUCN $=$ international union for conservation of nature

\section{DISCUSSION}

Some of the species such as Long-tailed glossy Starling Lamprotornis caudatus, Black-headed Lapwing Vanellus tectus and Barn Owl Tyto alba were also encountered by their dead body in the study area as shown in (Plate 2) is just natural dead. The abundance 


\section{International Journal of Current Science Research and Review}

ISSN: 2581-8341

Volume 04 Issue 12 December 2021

DOI: 10.47191/ijesrr/V4-i12-18, Impact Factor: 5.825

IJCSRR@ 2021

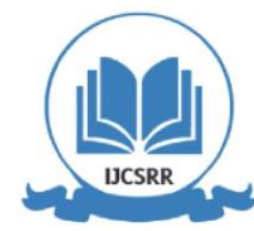

www.ijcsrr.org

of family Columbidae might be as a result of rice farming that is predominant in the area. The result is in contrast with the findings of Sabo (2016) who conducted a study in the same ecological area of Hadejia-Nguru wetlands and observed that only 135 species against the 50 species were identified along the RB. Similarly, Odewumi et al., (2017), reported that there were fewer number of 35 bird species belonging to 20 families were identified and recorded, the common species identified in includes Great egret (Ardea alba), Spur winged lapwing (Vanellus spinosus), Black Kite (Milvus migrans), Cattle egret (Bubulcus ibis) in Owena Multipurpose Dam, Ondo State, Southwest, Nigeria. The similarity with the present study might be due the fact that both studies were conducted around aquatic environment. The result of the bird species in present study area is lower than those reported by Okosodo et al., (2016) which was conducted in a different ecological area of Old Oyo National Park Southwest Nigeria. The author identified 149 species belonging to 52 families against the 50 species and 28 families identified in the present study area. The high number of bird species recorded may be connected with the land size as the park covers a land area of approximately 251,200 and also, the time of the research differs as Okosodo et al., (2016) undertook the research in both dry and wet season in, where this research was conducted in May and June, 2018 at the time when most of the migrants' bird species have gone from the study area. However, Lameed, 2011 reported a total number of 135 bird species in 40 families during a survey in Dagona-Waterfowl Sanctuary of Chad Basin National Park which is in the same ecological area with present study area, the differences might be due to the irrigation farming activities in the study area. This agrees with the finding of (Sandstrom et al., 2005), that human disturbed areas provide a heterogeneous habitat which usually attracts human tolerant bird species only, species that can co-exist with humans such as Redbilled Firefinch, pied crow, Cattle egret, Laughing dove, Speckle pigeon.

In the other hand result of the study also indicated that a total of six (10) species of small mammals belonging to four (8) families were identified. The result also shows that the family Muridae has (3) frequency which was the highest number of species per family identified in the study area, this might be connected with the fact that Muridae family are the most common small mammals (Rodent) in the study area, this study is in line with the findings of (Adam et al, 2021) whose reported a total of Nine (9) small mammal species belonging to seven (7) families were recorded in Federal University Gashua and the family Muridae has the highest number which represented by three (3) individual species while Leporidae, Erinaceidae, Nesomyidae, Gerbillinae, Soricidae, Pteropodidae and Sciuridae has the lowest number of representation with each recording One (1) species, in which both studies were conducted in Bade Local Government area of Yobe state, although the methodology differ the present study used line transect while former used captured mark recaptured method. The higher number of rodent species over other small mammal species in the study area may be attributed to the availability of food as (rodents feed on large variety of food), and their resilience in readily adapting to different modified habitats features. This result corresponds with reports of Koteler and Brown (1988). However, the similar observation by Akpan, et al., (2015) reported a total of seven (7) species of small mammals belonging to three (3) orders: Rodentia, Carnivora and Pholidota were encountered in Idu, Akwa Ibom State, Nigeria.

The study also indicates that Brown rat and short tail manicoot rat were identified by three methods that are direct sighting, dead animal and burrow. This is because the two species of mammals are commonly found around the river bank where they feed and hide in the shrubs the present of shrubs called Giant sensitive plant Memosa invisa which are commonly found around the river bank as it provides hide out for some wild animal species. This result correspond with report of Marcelllo et al., (2018) that food availability influence rodent abundance. (Tyowua, 2012) and they also burrow their holes around the flood plain and farm land as shown in (Plate 1). Most of the small mammal species encountered in the study area were rodents this may be attributed to the availability of food shelter and water (rodents feed on large variety of food), because of their resilience and ability to adopting modified habitats. Most of the small mammal species encountered in the study area were rodents this may be attributed to the availability of food, water and cover (rodents feed on large variety of food) and their resilience in adopting to modified habitats. The report of this study on the conservation status of both avifauna and small mammal species around the segment area of river Yobe, is similar with the report of (Sabo, 2016) who found that Majority of birds species felled under LC least concern only few felled under NT, NE and vulnerable at the Hadejia-Nguru Wetlands in which both study areas are in the vegetation zone.

The study also indicates that Brown rat and Short tail manicoot rat were identified by three methods that is direct sighting, detecting their dead animal body and burrow. This is because the two species of small mammals (rodent) are commonly found around the river bank because of the present of food, water and shrub grass which serves as shelter as well as escape ground. 


\section{International Journal of Current Science Research and Review}

ISSN: 2581-8341

Volume 04 Issue 12 December 2021

DOI: 10.47191/ijcsrr/V4-i12-18, Impact Factor: 5.825

IJCSRR@ 2021

WWw.ijesrr.org

\section{CONCLUSION}

Conclusion were drawn from the findings of the study, a total of Fifty (50) Species of birds belonging to Twenty eight (28) families were recorded. All species recorded occurred around the River Bank (RB) area, Twenty Nine (29) species occurred around Farm Lands (FL) and Ten (10) species in Flood plain (FP) areas respectively. Six (6) species; Great egret Ardea alba, Crested lark Galerida cristata, Abyssinian roller Coracias abyssinicus, Rose Ringed Parakeet Psittacula krameri, Bush petronia Gymnoris dentata, Northern grey-headed sparrow Passer griseus occurred across all three (3) habitat types The findings of the study further shows that the highest number of species was found in the family Columbidae Six (6) The low number of may be due to the human disturbance such as farming and pastoral herding activities in the study area. Another reason may be due to the time of year in which the study was conducted in the period whereby Migrant, and Vagrant species may have not been seen. In the other hand result of the study also indicated that a total of Six (6) species of small mammals belonging to Four (4) families were identified. The result also shows that the family Muridae has (3) frequency which was the highest number of species per family identified in the study area, this might be connected with the fact that Muridae family are the most common small mammals species.

\section{REFERENCES}

1. Adam, L. I., Gambo A. A., Eveso, J. O., Mohammed A., Ya 'u M. A. and Modu M. B. (2021). Preliminary study on Composition and Ecological distribution of Small Mammal Species in Federal University, Gashua, Yobe State Northeast Nigeria Journal of Research in Forestry, Wildlife and Environment 134

2. Adamu, I. A. (2006). An Assessment of Floristic Composition of Kwiambana Game Reserve, A Ph.D. Thesis, Presented to the Department of Geography, Usmanu Danfodiyo University, Sokoto (Unpublished). 122.

3. Akosim, C. and Mbaya, Y. P. (2014). Species list and Status of Mammals and Birds in Chingurmi-Daguma Sector of Chad Basin National Park, Nigeria. Canadian Open Wildlife Ecology Journal 1 (1): 3, available online at http;//crpub/journal PhD.

4. Akpan, A. U., Esenowo, I.K., Egwali, E.C. and James, S. (2015). The checklist and Abundances of Small Mammals in Idu, Akwa Ibom State, Nigeria. Journal of Applied Science. Environment. Manage. 19 (1): 71 - 75 Full-text Available Online at www.ajol.info and www.bioline.org.br/ja.

5. Atiku, M., Malami, A. A., Abare, A. Y. and Anokye, R. (2014). A survey of wildlife populations at Wassaniya forest reserve in Sokoto State, Nigeria international journal of advance agricultural research.vol. 2 114-115

6. Avenant, N (2011). The potential utility of rodents and other small mammals of indicators of ecosystem integrity of South African grasslands. South Africa Journal of Wildlife Resources. 38: 626-639.

7. Berthold, P. (2001). Bird migration: a general survey. Oxford University Press, Oxford, UK.

8. Bibi, F. and Ali Z. (2013). Measurement of Diversity Indices of Avian Communities at Taunsa Barrage Wildlife Sanctuary, Pakistan Journal of Animal \& Plant Sciences. 3: 469-474.

9. Castelletta, M., N. S. Sodhi, and R. Subaraj. (2000). Heavy extinctions of forest avifauna in Singapore: lessons for biodiversity conservation in South-East Asia. Conservation Biology 14:1870-1880. Chebera Churchura National Park, Ethiopia. Trop. Eco 55(2): 221-22

10. Chung, K.P.S. and Corlett, R.T. (2006), "Rodent diversity in a highly degraded tropical landscape: Hong Kong, South China", Biodiversity and Conservation, Vol. 15, pp. 4521-4532.

11. Datiko, D; Bekele, A (2014). Habitat association and distribution of rodents and insectivores in

12. David MM, Cesar P, Francisco AC (2009). Avian communities' preferences in recently created agricultural wetlands in irrigated landscapes of semi-arid areas. Biodiversity Conservation, 18: 811-928

13. Google Earth Image, Open Source Software (c) (2017) https://earth.google.com/kmlpreview/

14. Hamidu, D. (2015). Agricultural Land Use in Gashua and its Environs in Geography of Gashua, Department of Geography Umar Suleiman College Education Gashua. 27-28.International Union for the conservation of nature

15. Igbokwe, J. O., Awodiran, M. O., Oladejo, O. S., Olayemi, A. O., \& Awopetu, J. I. (2016). Chromosomal analysis of small mammals from southwestern Nigeria. Mammal Research,61, 153-159.

16. IUCN, Internatio Union for the Conservation of Nature. (2009). Komadugu Yobe Intergraded Management Project: Komadugu Yobe River Nigeria www.Kybproject.net/komadugu Yobe-River-Nigeria 


\section{International Journal of Current Science Research and Review}

ISSN: 2581-8341

Volume 04 Issue 12 December 2021

DOI: 10.47191/ijcsrr/V4-i12-18, Impact Factor: 5.825

IJCSRR@ 2021

www.ijcsrr.org

17. Kingdon, J. (2015). Field Guide to African Mammals Second Edition. Downloaded on 02 January 2018.

18. Kole, A.S. (1997) Dam Politics in Northern Nigeria: the Case of the Kafin zaki Dam journal on Refugees (16): 3.

19. Kwaga, B.T., Iliya1 D., Ali A., Khobe D. 2017 Avifauna Abundance and Diversity in Jos Wildlife Park, Nigeria Agricultural Science and Technology, vol. 9, No 3, pp 234 - 239.

20. Lameed, G. A. (2011) Species Diversity and Abundance of Wild Birds in Dagona-Waterfowl Sanctuary Borno State, Nigeria African Journal of Environmental Science and Technology 5(10): 855-866.

21. Marcelllo,G.J.,Wilder, S. M and Mecikle, D.B. (2008) Population Dynamic of a Generalist Rodent in Relation to Variability in Pulse Food Resources in Fragmented Landscape Journal of Animal Ecolgy. Are Microbiology Preference sof Coexisting Specie sunder Selection and Adaptive? Ecology 79: 656-670

22. Mbaya, Y. P. and Malgwi, H. (2010). Species List and Status of Mammals and Birds in Sambisa Game Reserve, Borno State, Nigeria Journal of Research in Forestry, Wildlife and Environment. Vol. (2) 1.1 36-137.

23. Michel, N., Burel F., Legendre P. and Butet A. (2007). Role of habitat and landscape in structuring small mammal assemblages in hedgerow networks of contrasted farming landscapes in Brittany, France. Landscape Ecology;22(8):1241-53.

24. Nigeria National Biodiversity Strategy and Action Plan NBSAP. (2007). Retrieved September /28/ 2018 from www.cbd.int/doc/world/ng/ng-nbsap-01-en.pdf

25. Odewumi, O.S., Okosodo E.F. and Talabi O. (2017) Diversity and Abundance of Avian Species of Owena Multipurpose Dam, Ondo State, Southwest, Nigeria. Journal Biodiversity Bioprosphre Developmement 4: 163. doi:10.

26. Okosodo, E.F., Orimaye J.O. and Obasogie F.O. (2016) Avifauna Species Diversity of Covenant University Otta South Western Nigeria Greener Journal of Agricultural Sciences 6 (1), 017-027. Retrieved 22.

27. Ringim A. S; Sulaiman, I. M. (2017). A Checklist for Birds of Hadejia- Nguru Wetlands, Nigeria Dutse Journal of Pure And Applied Sciences (DUJOPAS) Vol. 3 No. 1.

28. Rosenberg, D. K., Swindle, K. A. and. Anthony R. G. (2003). Influence of prey abundance on northern spotted owl reproductive success in western Oregon. Canadian Journal of Zoology 81:1715-1725.

29. Sabo, B. B. (2016). Checklist of Bird Species at the Hadejia-Nguru Wetlands, Nigeria Global Advanced Research Journal of Agricultural Science 5(11) 405-412.

30. Safra J. E. (1998). The New Encyclopaedia Britanica, 15, 18th ed, Chicago, pp. 1-112.

31. Sandstrom U. G., Angelstam P, Mikusinski G (2005) Ecological diversity of birds in relation to the structure of urban green space. Landscape Urban Plan 77: 39-53.

32. Sekercioglu, C. H. (2006). Increasing Awareness of Avian Ecological Function. Trends in Ecology and Evolution 21, 464471.

33. Shimelis aynalem \& afework bekele (2008). Species Composition, relative abundance and distribution of bird fauna of riverine and wetland habitats of Infranz and Yiganda at Southern tip of lake Tana, Ethiopia. Tropical Ecology 49(2): 199209, 2008 ISSN 0564-3295 ( International Society for Tropical Ecology www.tropecol.com

34. Sivaperuman C. and Jayson, E. A. (2006). Status and conservation of bird fauna in the vembanad-Lole. Ramsar site Kerela, India. Conference on wetlands biodiversity. 31-37.

35. Sulaiman, I.; M. (2010). Bird Diversity and Abundance at the Hadejia-Nguru Wetlands Nigeria, Masters Dissertation. Aplori, University of Jos, Plateau State Nigeria

36. Tyowua, B.T., Agbelusi E.A, and Dera B.A. (2012). Evaluation of vegetation types and utilization in Wildlife Park of the University of Agriculture Makurdi, Nigeria. Research Article. 3 (1):1-5.

37. Wakawa, L., Aminu S., Yakubu, I. and Lawan, A. (2017). Tree Species Biodiversity of a Sahelian Ecosystem in NorthEast Nigeria Journal of Bartin Faculty of Forestry 19 (2): 166-173.

38. Yusuf, K .G., (2015). The Historical Revolution of Gashua Settlement, the Head Quarters of Bade Emirates in Geography of Gashua, Oladimegi S.A. (Ed.) Ibadan-Nigeria, Boga Press 4-5

Cite this Article: Adam, L. I., Abdullahi, M., Kwaga, B. T., Dadile, A. M., Danturai S. A. (2021). List of Species and Conservation Status of Avifauna and Small mammal around Bade Segment Area of River Yobe, Yobe State, Nigeria. International Journal of Current Science Research and Review, 4(12), 1743-1757 


\section{International Journal of Current Science Research and Review}

ISSN: 2581-8341

Volume 04 Issue 12 December 2021

DOI: 10.47191/ijcsrr/V4-i12-18, Impact Factor: 5.825

IJCSRR@ 2021

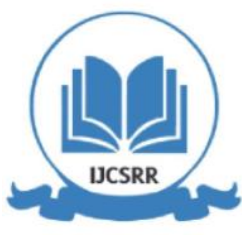

www.ijesrr.org

Plate I. Showing the General Features of the Identified Habitat Types along Bade Catchment Area of River Yobe
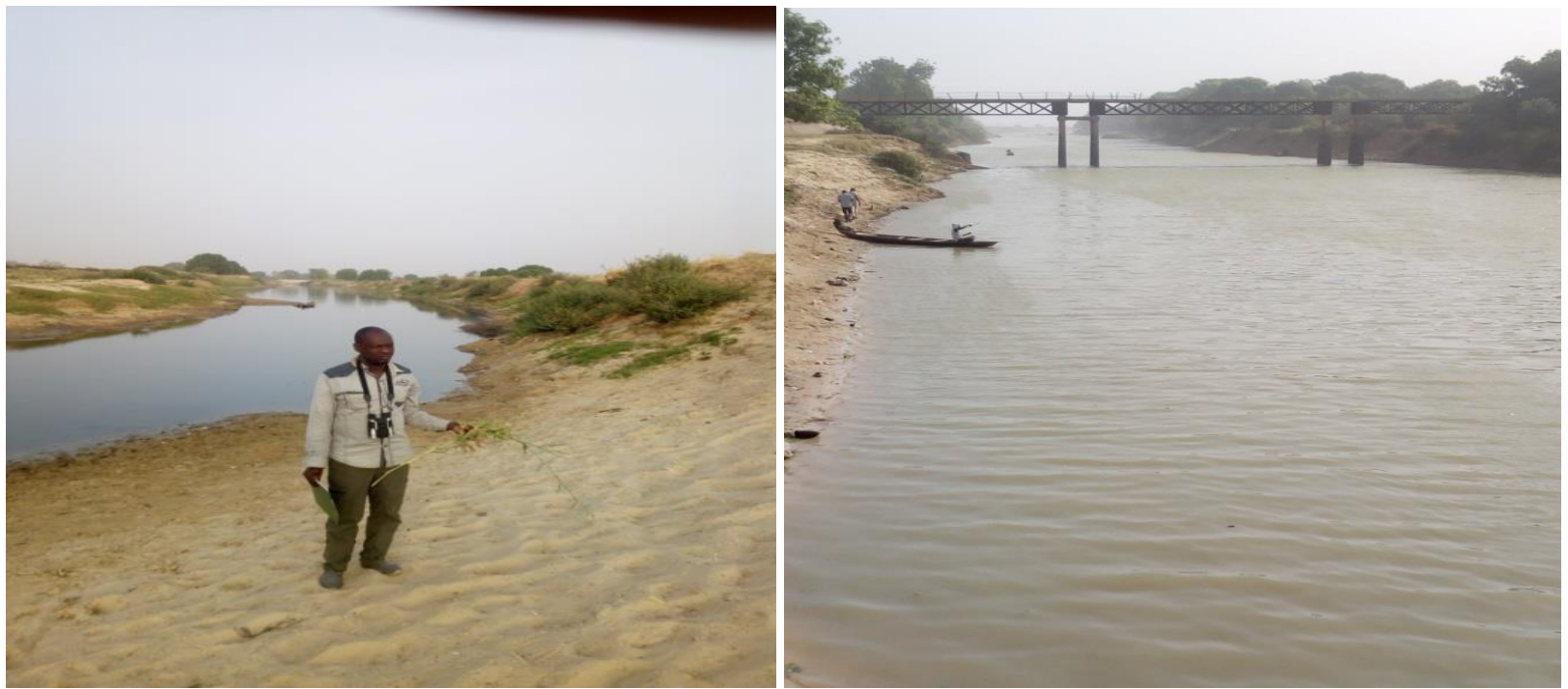

\section{River Banks}
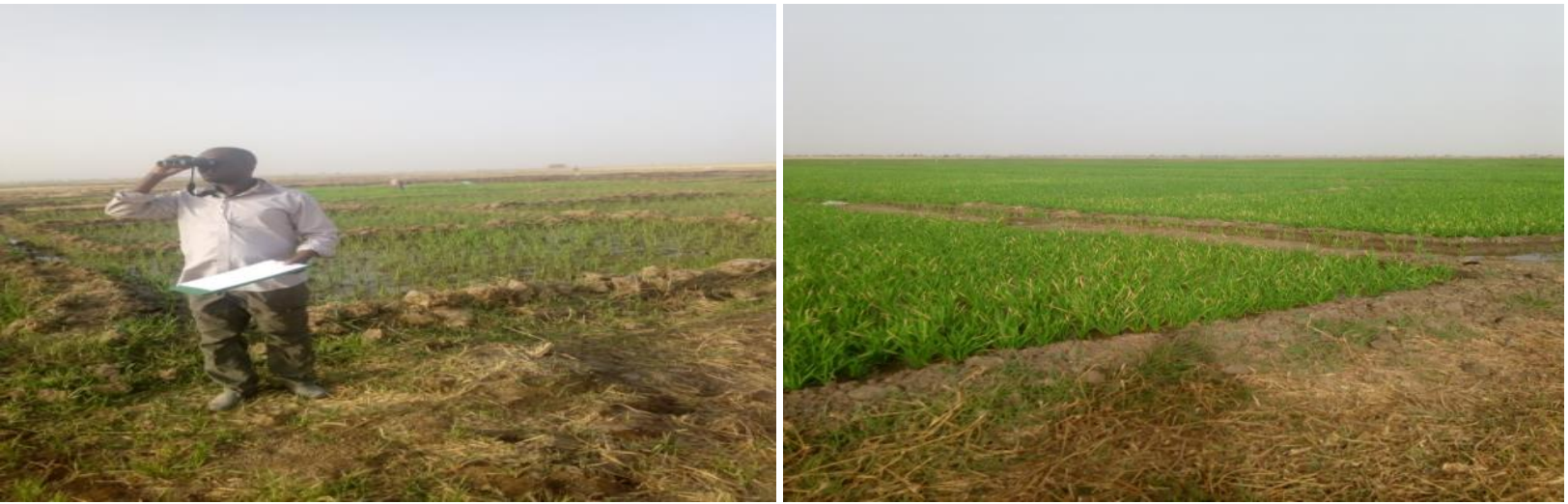

Farm Lands
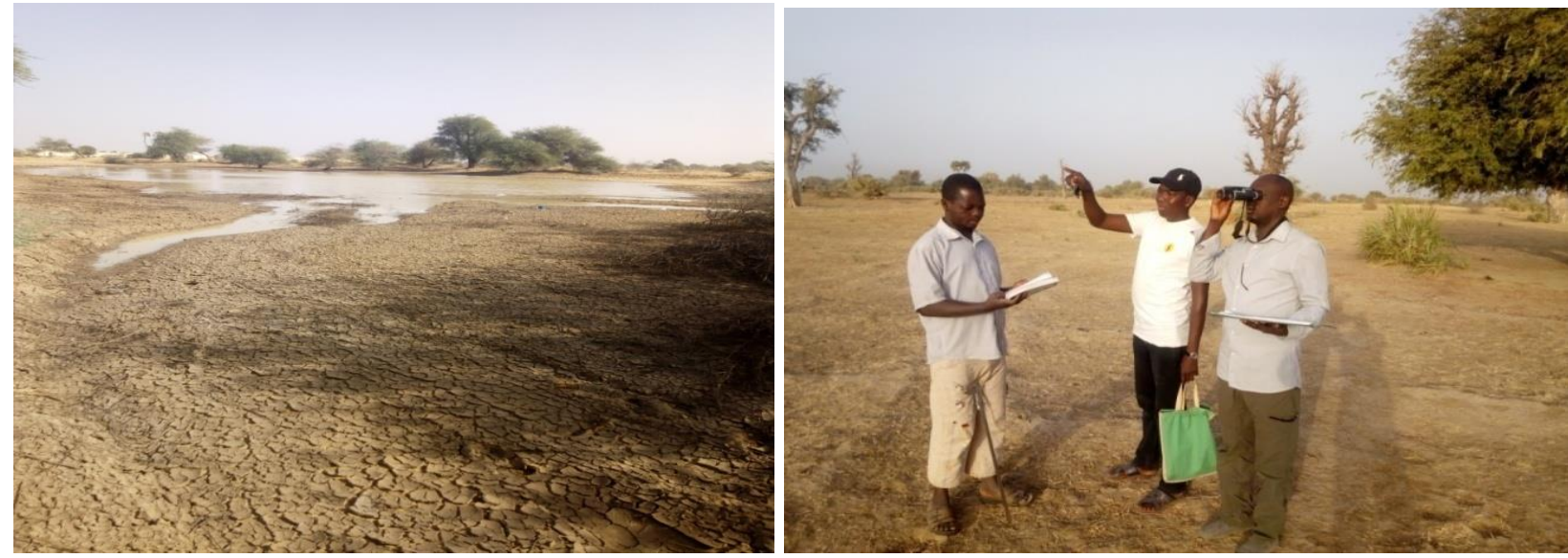

Flood Plain

Source: Field Survey (2019)

Above: Photographs showing the researcher and his assistance during data collection at the study area. 
International Journal of Current Science Research and Review

ISSN: 2581-8341

Volume 04 Issue 12 December 2021

DOI: 10.47191/ijcsrr/V4-i12-18, Impact Factor: 5.825

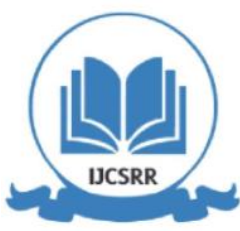

www.ijesrr.org

Plate 2. Photograph showing alive and dead of bird species identified during field survey in the study area
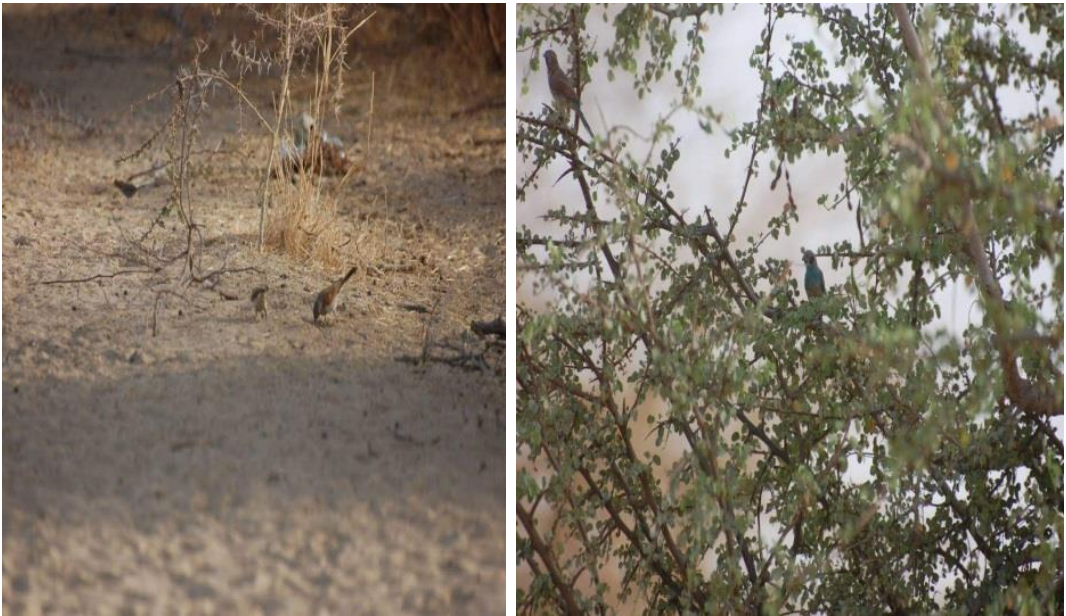

Red-Cheeked Cordon Bleu
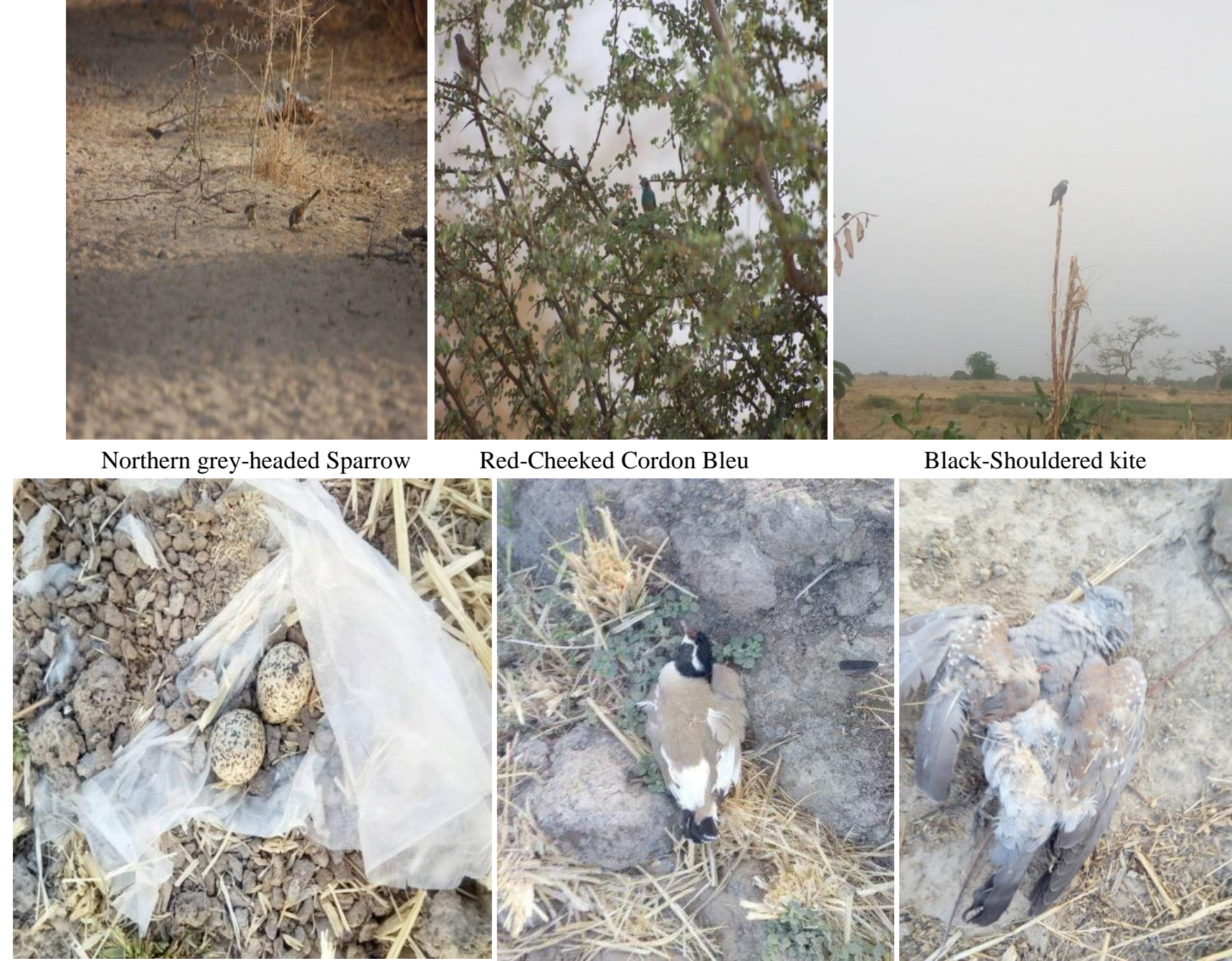

Black-Shouldered kite

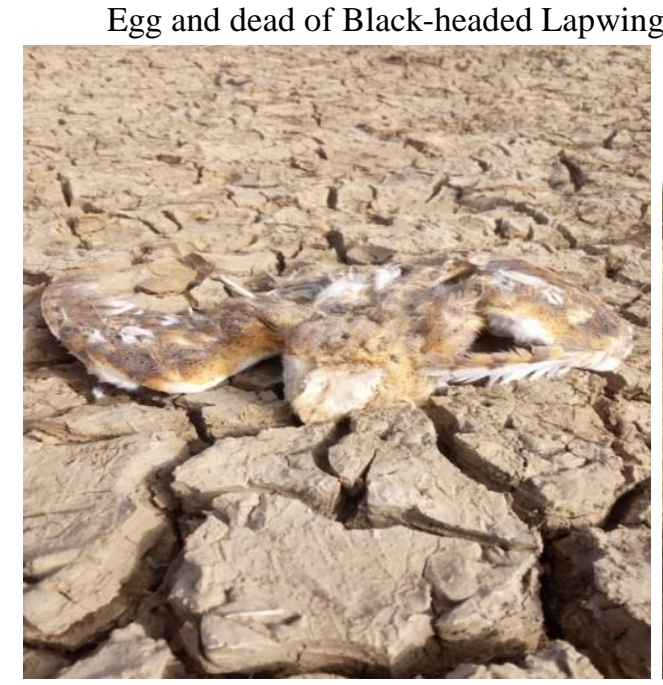

Barn Owl

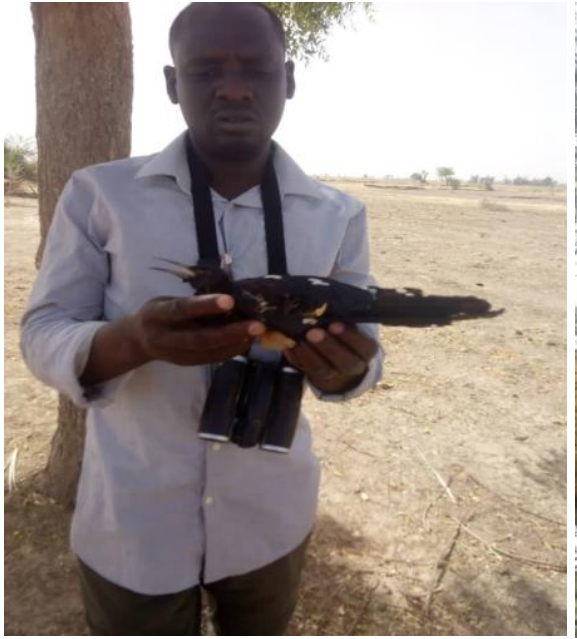

Long-tailed glossy Starling

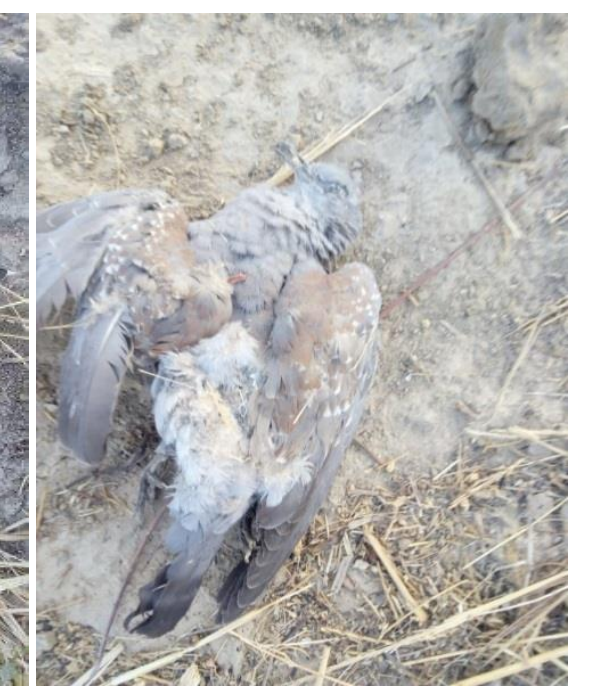

Dead body of Speckled Pigeon

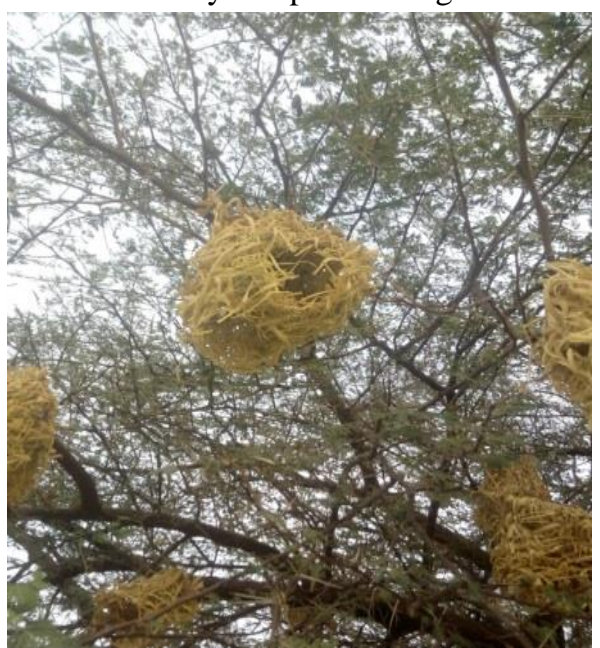

Identified Bird Nest

Source: field survey (2019) 
International Journal of Current Science Research and Review

ISSN: 2581-8341

Volume 04 Issue 12 December 2021

DOI: 10.47191/ijcsrr/V4-i12-18, Impact Factor: 5.825

IJCSRR@ 2021

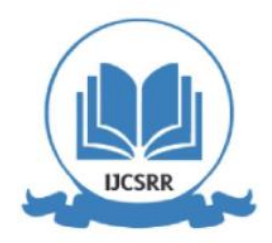

www.ijesrr.org

Plate 3. Photographs showing dead body of and small mammal (Rodents) species observed along bade catchment area of river Yobe
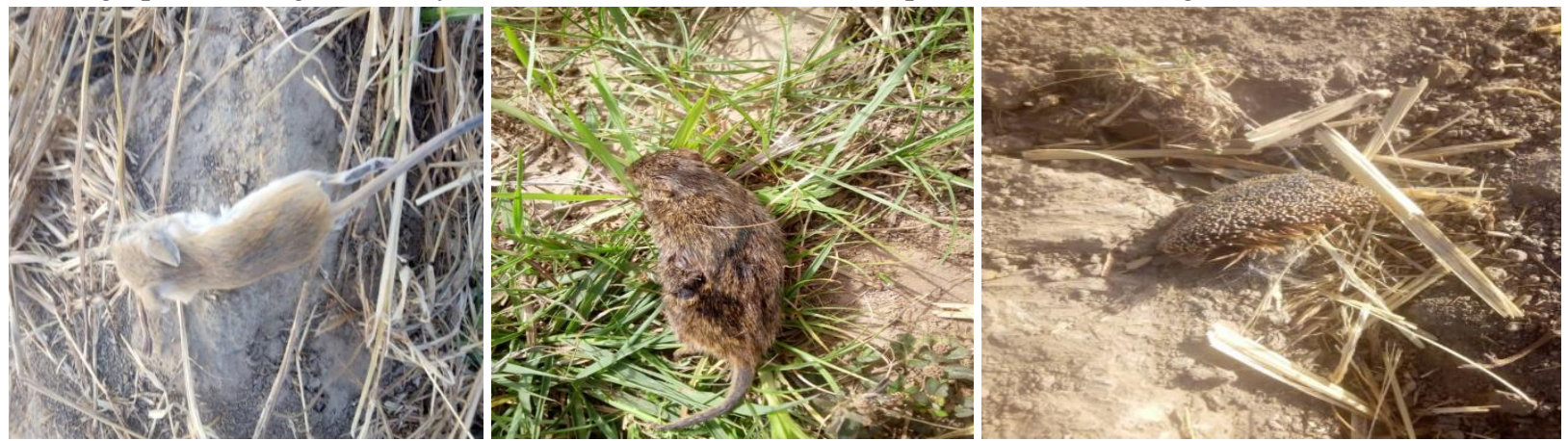

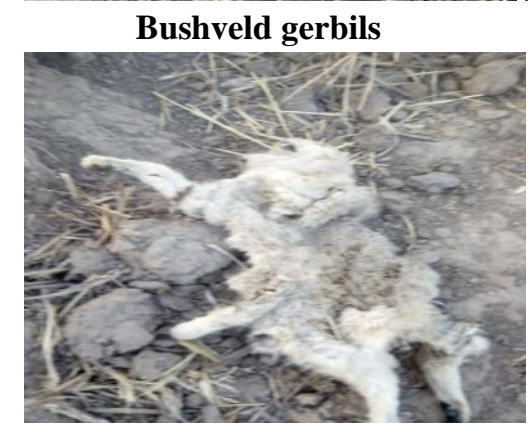

Dead body Wild cat
Common Mice

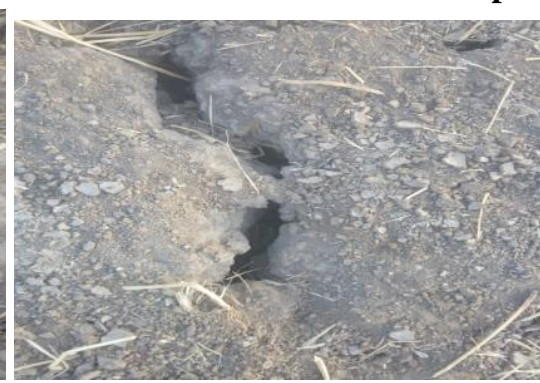

Felis silvestris
Spines \& Quills of Desert Hedgehog

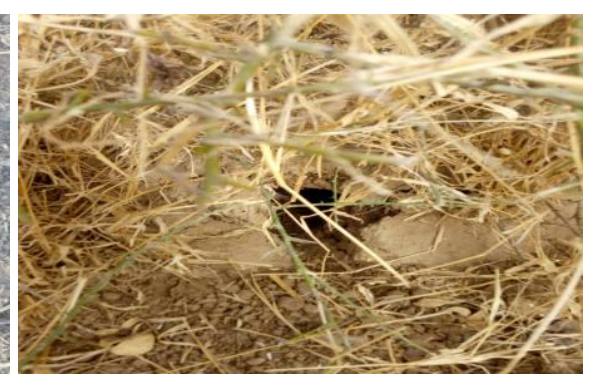

Microhabitat (Burrows) of some rodents

Plate 4. Photographs showing small mammal species identified at bush meat market in study area

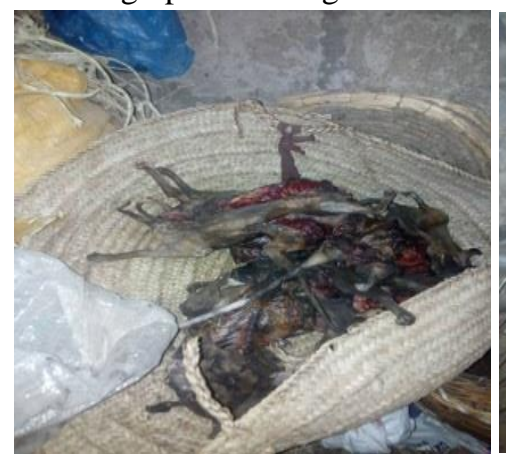

Rusted bush meats

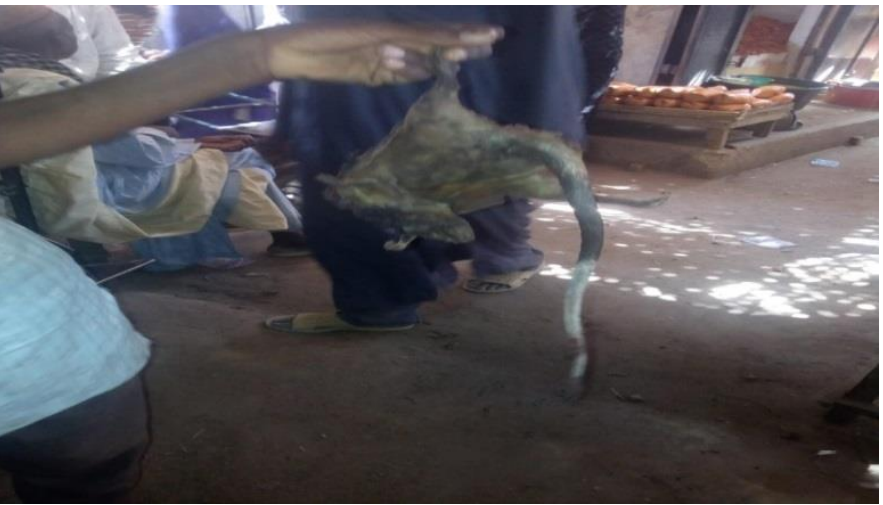

Giant porch rat Cricetomys gambianus

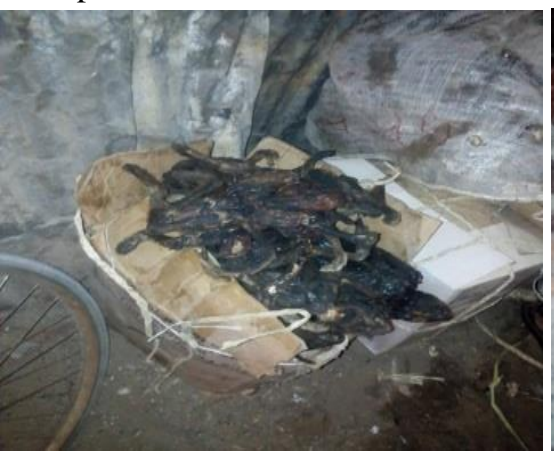

African Mongoose

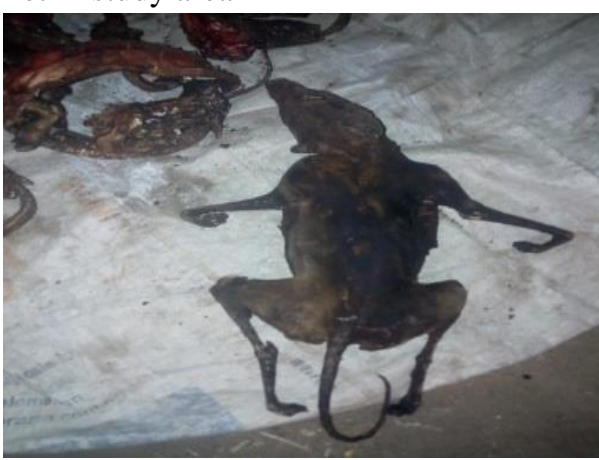

Suricata suricatta

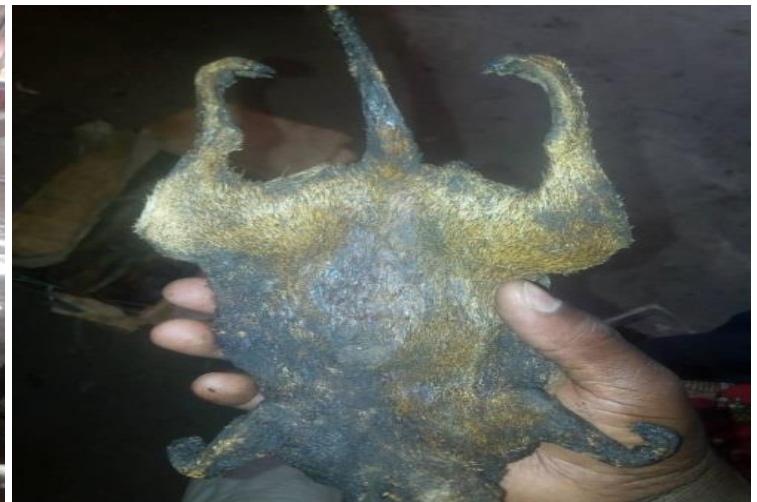

Squirrel Xeru erythropu

Source: field survey (2019) 